\title{
Space-Base Disaster Management and Poverty Reduction in Nigeria
}

\author{
Emmanuel Okokondem Okon ${ }^{1}$
}

${ }^{1}$ Department of Economics, Kogi State University, Anyigba, Kogi State, Nigeria

Correspondence: Department of Economics, Kogi State University, Anyigba, Kogi State, Nigeria, E-mail: tonydom57@yahoo.com. Tel: +2348023275716

Received: January 12, 2018

Accepted: January 12, 2018

Online Published: January 20, 2018

Abstract

Poverty level in Nigeria is at variance with the country's immense wealth and natural disasters are on the increase and claiming lives as well as properties. This paper looks at the use of space base technology in disaster management and how disaster management can be integrated into poverty reduction to help reduce the vulnerability of poor and protect their livelihoods and development gains. It starts by conceptualizing poverty and vulnerability and proceeds to examine Nigeria's economy, poverty and natural disaster. Thereafter, the paper looks at the introduction of space technology in disaster mitigation and management in Nigeria and the challenges associated with it. Suggestions are made for effective use of space technology for disaster management and poverty reduction in Nigeria.

Keywords: Natural Disaster, Space Technology, Disaster Management, Poverty Reduction.

\section{Introduction}

Nigeria is endowed with enormous human and natural resources which if efficiently harnessed and managed will ensure that Nigeria's immense potentials are realized. Current events in Nigeria affirm the description of the country as a paradox by the World Bank in 1996. The paradox is that the poverty level in Nigeria is at variance with the country's immense wealth. It is a general belief that if there is an increase in per capita income, simultaneously with a more even distribution of income, such would lead to poverty reduction. Reduction in the level of unemployment is also perceived as a necessary condition for the realization of increased income per capita. Development is not just a matter of growth in income per capita, as it is possible to record high growth rate in income per capita, while the people continue to live in abject poverty; lacking the basic necessities of life. This is a situation peculiar to Nigeria today. The momentum of growth derivable from a sector has a little direct impact on bulk of the population. Generally, the priorities and strategies enunciated in virtually all the development plans show that agricultural production is always accorded the highest priority (FRN, 1990; FRN, 1981; FRN, 1970 as cited in Obadan, n.d.). Even in the Structural Adjustment Programme document, agriculture was considered one of the critical sectors, whose rehabilitation was crucial to the success of the programme (FRN, 1986 as cited in Obadan, n.d.). An appendage of agricultural development is rural development. Against the background that the poor are located in rural areas, and are mainly engaged in agriculture. Unfortunately, in 2012 Nigeria suffered its worst flood disaster in 40 years. More than 2 million people were displaced, homes and farmlands were destroyed (EU,2013), and the risk of a similar large-scale disaster is high.

Natural incidence like earthquakes, rainstorms, hurricanes, cyclones, flooding, drought and erosion can induce poverty too and poverty can lead to diseases, high mortality among infants, increase in school drop outs, high juvenile delinquency rates, higher levels of teenage pregnancy, and economic dependency on others, prostitution, homicides and other forms of violence (Tiena, 2010). Poverty greatly reduces populations.

Much wider recognition is needed of the fact that natural disasters, particularly storms and floods, are becoming endemic and that their increasing frequency and severity can slash economic growth and development in Nigeria. In light of this, the paper examines Nigeria's use of space technology in its disaster management efforts with the view of reducing poverty. Disasters triggered by natural events often raise poverty rates in the affected regions and destroy achieved development progress. Furthermore, poorly-planned development and inappropriate poverty reduction measures can increase vulnerability to external natural shocks. "If development efforts are not appropriate to existing environmental factors, and their impacts on the environment have not been assessed properly, they can 
increase vulnerability to disasters"(Özerdem, 2003). Consequently, vulnerability is strongly linked to poverty, as is disaster risk management to poverty reduction (Eschborn, 2005). The second section of this paper attempts to conceptually show this relationship. The third second presents some stylized facts on Nigeria. The fourth section examines some disaster risk management and application of space technology to disaster management. Section five looks at Nigeria's space programme, challenges and way forward while section six concludes.

2. Conceptual Illustration

A disaster is a swift, catastrophic event that seriously disrupts the functioning of a community or society and causes human, material, and economic or environmental losses that exceed the community's or society's ability to cope using its own resources (IFRC, 2012). The combination of hazards, vulnerability and the inability to reduce the potential negative consequences of risk results in disaster. As a result, disasters influence the mental, socioeconomic, political as well as the cultural state of the affected area. Hence, disasters are considered as the consequence of inappropriately managed risk (Quarantelli, 1998). These risks are the product of a combination of both hazard/s and vulnerability. Therefore, hazards that strike in areas with low vulnerability are less likely to become disasters, as is the case in uninhabited regions (James et al., 2013).

Disasters are generally grouped into two types, namely anthropogenic or human-made and natural. Anthropogenic or human-made disasters are associated with human action or inaction. Examples of such disasters include: technological failures, industrial accidents, oil spills, transportation accidents and nuclear explosions/radiation.

A natural hazard is a geophysical, atmospheric, or hydrological event that has potential for causing harm or loss (Benson and Clay, 2004). Usually, these events are both uncommon and extreme, in the perspective of the range of natural phenomena such as rainfall, tropical storms, flooding, and seismic tremor or earthquake. Hence, there is a need to determine risk. This is understood to be "a combination of the probability, or frequency, of occurrence of a defined hazard and the magnitude of the consequences of the occurrence" (Royal Society, 1992). A natural disaster is the occurrence of an abnormal or infrequent hazard that affects vulnerable communities or geographic areas, causing substantial damage, disruption, and perhaps casualties and leaving the affected communities unable to function normally (Benson and Clay, 2004).

From an economic perspective, a disaster implies some combination of losses, in human, physical, and financial capital, and a reduction in economic activity such as income generation, investment, consumption, production, and employment in the "real" economy. There may also be severe effects on financial flows such as the revenue and expenditure of public and private bodies (Benson and Clay, 1998). Vulnerability is the potential to suffer harm or loss, expressed in terms of sensitivity and resilience or of the magnitude of the consequences of the potential event (Benson and Clay, 2004). The sensitivity of economic behavior to a disaster shock is reflected at a macroeconomic or sectoral level in the deviation of economic aggregates from the trends that were expected without taking the effects of the event into account.

Although this paper focuses on natural disaster, generally, disasters can have potentially significant implications for public finance, increasing expenditure and simultaneously reducing domestic revenue, in turn resulting in increased domestic or external borrowing, substantial alterations to existing investment, and recurrent expenditure plans or monetary expansion(Benson and Clay, 2004). Figure 1below is a schematic evolution of disasters.

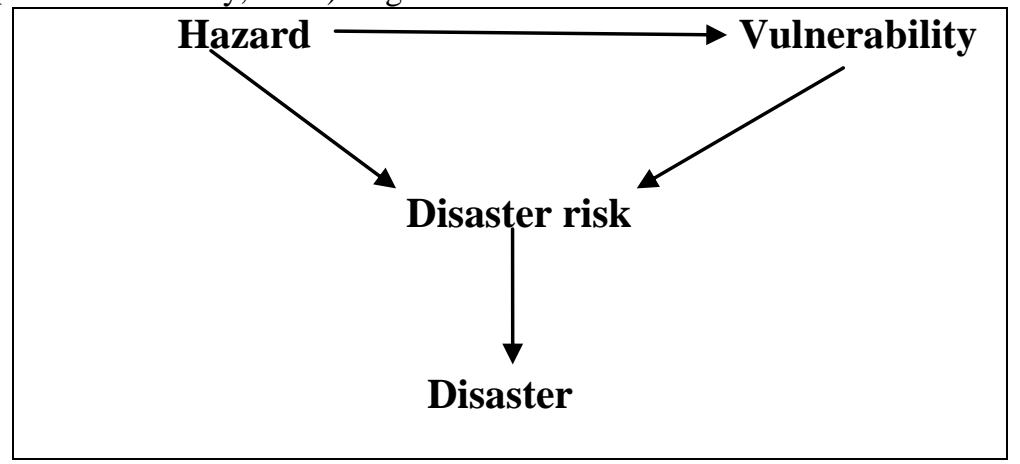

Source: Adapted from (Eschborn, 2005)

Figure 1: schematic evolution of disasters

The relationship between the level of development of an economy and the impact of a disaster is particularly complex. Influences include the physical infrastructure, the degree of sectoral and geographical integration, economic specialization, the coverage and robustness of the financial sector, government revenue raising capabilities and the openness of the economy. This complexity in part reflects the fact that development itself is a non-linear process and that there are many different paths of development (ODI, 2005). Least-developed economies are widely perceived as most vulnerable, experiencing the greatest direct losses relative to a country's wealth. 
At higher levels of development, the financial costs of capital losses are massive (as illustrated by Kobe and Hurricane Katrina), but the economic impacts of disasters are proportionately less. This partly reflects increased investment in mitigation and preparedness measures, improved environmental management, greater access to financial resources and lower associated opportunity costs and a reduction in the scale of absolute poverty and thus of household vulnerability(ODI, 2005). A greater share of privatesector economic assets is also likely to be adequately insured against disaster and the burden diffused by global reinsurance. The combined effects of changes in sensitivity (direct and indirect impacts) and the time to recover (resilience) suggest, as illustrated in Figure 2, a Kuznets' Curve or inverted U relationship between economic development and disaster vulnerability.

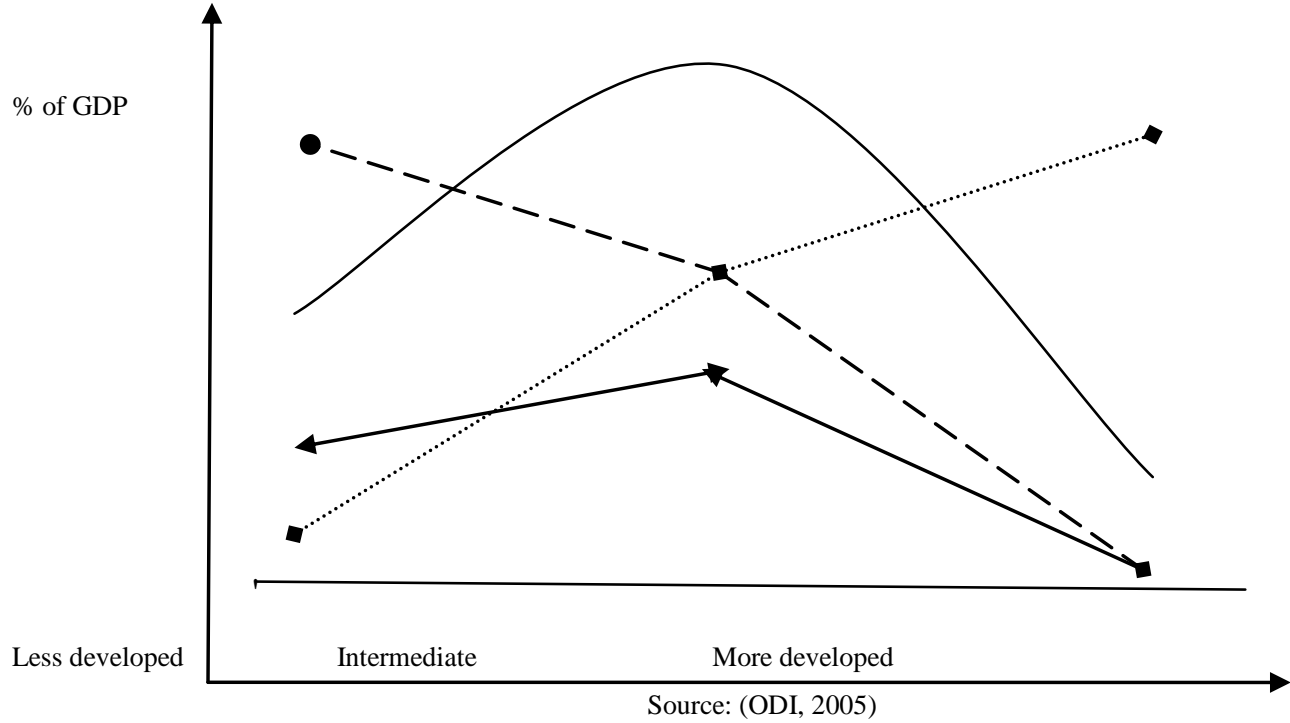

Figure 2: a Kuznets' Curve or inverted U relationship between economic development and disaster vulnerability

According to Okuyama (n.d.), with the increasing complexity of society and interdependency within and across countries, recent studies found that this negative relationship between development level and disaster losses appears not so straightforward: total impact over GDP per capita has an inverted "U"curve relationship. Least developed countries tend to have simple economic structures, such as agriculture, so that the impact may not spread to the entire system; higher-income level countries have sufficient financial and technological resources to better manage disaster risks through the implementation of countermeasures and to better manage the adverse impacts of disaster; and middle-income level countries with some diversifications seem more secure, but the higher order effects can be much greater and thus the total impacts from a disaster can be larger than in a simple agro-economy's (see Figure 3 below)

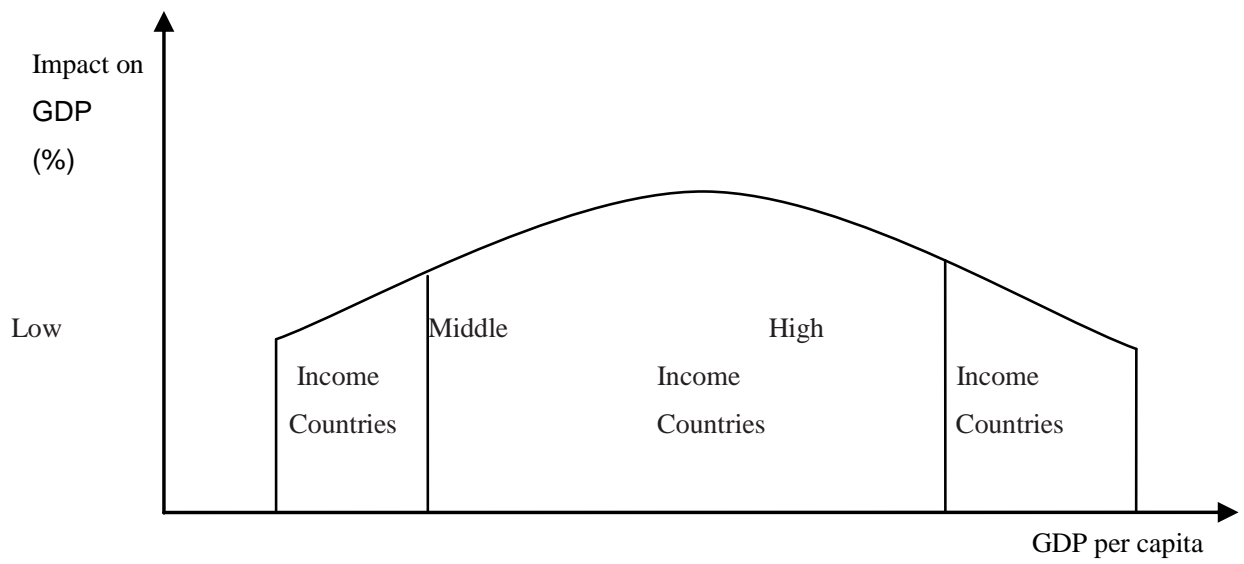

Source: (Okuyama, n.d.)

Figure 3: Inverted U Curve Relationship 
Vulnerability is not only a key concept in the discussion about disaster risk management, but it also is a central issue in the debate on poverty. Here, attempt is made to look at the connection between poverty reduction and disaster risk management because their inter-linkage is seen as essential for sustainable development. It proceeds from a complex notion of poverty that is not confined to the economic component, but also encompasses participation, education and health.

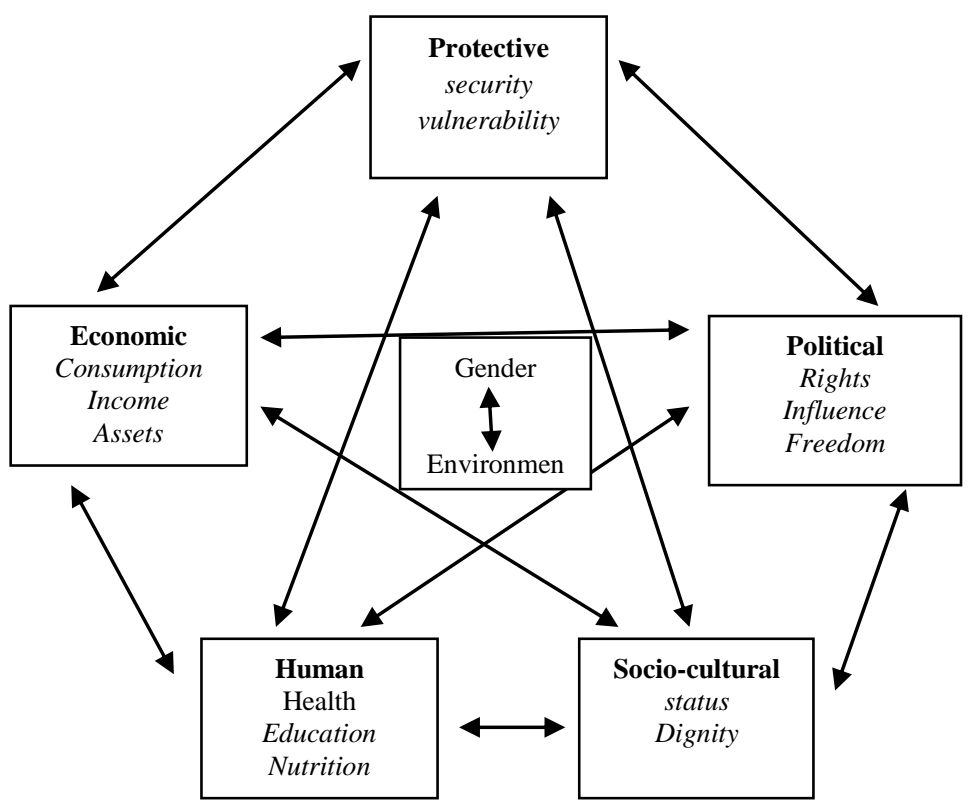

Source: Adapted from OECD (2001)

Figure 4 - Dimensions of poverty

As depicted in Figure 4 above, each box represents an important dimension of poverty, which affects - and is affected by - all the others. Household members may consume little and be vulnerable partly because they lack assets, often because of inadequate income, poor health and education, or because they lose their few productive assets as a result of shocks. Lack of human rights and political freedom indicates a risk of violent conflict shocks. Vulnerability and social exclusion hamper human and political capabilities, reducing incomes and assets, and so on. The fact that different dimensions of poverty are tightly interrelated, while still distinct and imperfectly correlated, is a major reason for a multidimensional concept" (OECD 2001).

Natural hazards disrupt poor people's livelihoods, and poor people are often more vulnerable to natural hazards. The negative and positive aspects of the relationship between vulnerability/disaster and poverty can be divided in four realms as show below in Figure 5.

Poverty reduction realm

\begin{tabular}{c|c}
$\begin{array}{l}\text { Short-sighted poverty } \\
\text { reduction measures can increase } \\
\text { vulnerability }\end{array}$ & $\begin{array}{c}\text { Poverty reduction can reduce } \\
\text { vulnerability }\end{array}$ \\
\hline Negative realm Positve realm & Disasters can provide \\
Disasters can set back & poverty reduction opportunities \\
poverty reduction efforts &
\end{tabular}

Source: Adapted from: UNDP (1994)

Figure 5: The relationship between poverty and vulnerability to disasters

\section{Nigeria: Economy, Poverty and Natural Disaster}

Nigeria is a West African economy with a long coastline along the Atlantic Ocean. The country shares international borders with Benin, Chad, Cameroon and Niger. Nigeria ranks 32 in the world in terms of total area (see Figure 6 in 
Appendix). The terrain of the country consists of southern lowlands and plateaus in the central region. The south east region has a mountainous surface, while the north consists of plains. According to the 2009 estimates, the country has a total population in excess of 154 million, of which almost $70 \%$ live below the international poverty line (Economic Watch, 2010). Nigeria's economy is overly dependent on the petroleum sector. The economy is one of the most developed economies in Africa. According to the UN classification, Nigeria is a middle-income nation with developed financial, communication and transport sectors. It has the second largest stock exchange in the continent. The petroleum industry is central to the Nigerian economic profile. It is the $12^{\text {th }}$ largest producer of petroleum products in the world (Economic Watch, 2010). The industry accounts for almost $80 \%$ of the GDP share and above $90 \%$ of the total exports (Economic Watch, 2010). Outside the petroleum sector, the Nigerian economy is highly amorphous and lacks basic infrastructure. Several failed efforts have been made after 1990 to develop other industrial sectors.

Owing to the surge in international oil prices during 2007-08, Nigeria managed an annual GDP of US $\$ 352.3$ billion. The nation ranks 33 in the world in terms of GDP. The GDP per capita is US \$2,400(Economic Watch, 2010). See Table 1 below for some indicators of economic growth in Nigeria.

Table 1: Selected Macro-Economic Indicators of Growth (Percent)

\begin{tabular}{|c|c|c|c|c|c|c|c|c|c|c|c|c|c|}
\hline $\begin{array}{l}\text { Economic } \\
\text { Variables }\end{array}$ & 1991 & 1992 & 1993 & 1994 & 1995 & 1996 & 1997 & 1998 & 1999 & 2000 & 2001 & 2002 & 2003 \\
\hline $\begin{array}{l}\text { Real GDP Growth } \\
\text { Rate }\end{array}$ & 4.7 & 3.0 & 2.3 & 1.3 & 2.2 & 3.3 & 3.8 & 204 & 2.8 & 3.8 & 3.9 & 3.5 & 10.2 \\
\hline $\begin{array}{l}\text { Manufacturing } \\
\text { capacity utilization }\end{array}$ & 37.4 & 41.8 & 37.2 & 30.4 & 29.3 & 32.5 & 33.0 & 32.4 & 34.6 & 35.4 & 42.7 & 44.3 & 46.2 \\
\hline Inflation Rate & 13.0 & 44.6 & 57.2 & 57.0 & 72.8 & 29.3 & 8.5 & 10 & 6.6 & 6.9 & 18.9 & 12.9 & 14.0 \\
\hline $\begin{array}{l}\text { Credit to Private } \\
\text { Sector }\end{array}$ & 23.7 & 34.7 & 16.6 & 28.3 & 51.8 & 18.4 & 39.3 & 27.4 & 29.2 & 30.9 & 43.5 & 11.8 & 27.1 \\
\hline $\begin{array}{l}\text { Credit to } \\
\text { Government }\end{array}$ & 82.5 & 109.6 & 120.7 & 27.7 & 27.6 & -16.6 & -32.5 & 144.9 & 32 & -170.1 & 79.7 & $\begin{array}{l}6320 . \\
6 \\
\end{array}$ & 47.9 \\
\hline Domestic Credit & 46.3 & 73.0 & 75.9 & 29.2 & 36.0 & 12.0 & 16.9 & 46.8 & 30 & -23.1 & 74.8 & 56.6 & 32.7 \\
\hline $\begin{array}{l}\text { National } \\
\text { Unemployment Rate }\end{array}$ & 3.8 & 3.4 & 2.7 & 2.0 & 1.8 & 3.2 & 3.4 & 3.9 & 3.3 & 4.8 & 3.8 & 3.7 & 2.3 \\
\hline $\begin{array}{l}\text { Overall Balance of } \\
\text { Payment as a \% of } \\
\text { GDP }\end{array}$ & -4.9 & $\begin{array}{l}-18.3 \\
\end{array}$ & -5.1 & -4.7 & -3.1 & -5.6 & -0.8 & -8.4 & -9.8 & 6.3 & 0.4 & -10.3 & -2.2 \\
\hline
\end{tabular}

Source: Oyeranti and Olayiwola (2005)

Widespread poverty and lack of industrial resources are the biggest challenges for Nigeria. As indicated in Table 2, the incidence of poverty in Nigeria increased from 28.1 percent in 1980 to 88.0 percent in the year 2002. This percentage rate represent in absolute term 86 million people out of an estimated population of about 116.4 million people(Ijaiya, Ijaiya, Bello, and Ajayi, 2011). The poverty situation in Nigeria also depicts regional variation. For example, within these periods the poverty rate was higher in the northern agro-climatic zone at 40 percent compared with the middle and southern zones at 38 percent and 24 percent respectively (Francis et. al., 1996; FOS various issues). Similarly, Nigeria's rank in the Human Development Index in the year 2008 remained low (0.470), being the 158th among 182 countries (ADB, 2010). The use of socio-economic indicators like per capita income, life expectancy at birth (years), access to health care services, access to safe water, access to education, access to sanitation facilities, and electricity also depicts the extent of poverty in Nigeria. As indicated in Table 3, the rate of poverty in Nigeria has not shown any remarkable reduction when viewed from these indicators and when compared with some countries in Africa. For instance, apart from the early 1980s when the nation's per capita income witnessed an increase the situations in the 1990s and early 2000 were pathetic(Ijaiya et al., 2011). The life expectancy at birth (years) does not provide a better level of well-being in the country (47 years in 2007), more so when compared with those of countries like Mauritius and Tunisia that had 73 and 74 years respectively in 2007 (ADB, 2010).

The 1980s to the 2000s had witness the introduction of new strategies/approaches to poverty reduction. Key among them are the basic needs and capabilities/entitlements approaches, participatory development, social capital, community self help, good governance and human right approaches to poverty reduction ( Boeniniger 1991; Picciotto 1992; Woolcock and Narayan 2000; United Nations, 2002; United Nations 2004). In Nigeria, various efforts were made by the government, non-governmental organizations and individuals to reduce poverty in the country. According to Ogwumike (2001) poverty reduction measures implemented so far in Nigeria focuses more attention on economic growth, basic needs and rural development strategies. The economic growth approach focuses attention on rapid economic growth as measured by the rate of growth in real per capita GDP or per capita national 
income, price stability and declining unemployment among others, which are attained through proper harmonization of monetary and fiscal policies (Ijaiya et al.,2011). The basic need approach focuses attention on the basic necessities of life such as food, health care, education, shelter, clothing, transport, water and sanitation, which could enable the poor live a decent life. The rural development approach focuses attention on the total emancipation and empowerment of the rural sector. Ogwumike (2001) grouped the strategies for poverty reduction in Nigeria into three eras - the pre-SAP era, the SAP era and the democratic era.

In the pre-SAP era, the measures that were predominant were the Operation Feed the Nation, the River Basin Development Authorities, the Agricultural Development Programmes, the Agricultural Credit Guarantee Scheme, the Rural Electrification Scheme and the Green Revolution. In the SAP era the following poverty reduction measures were introduced; the Directorate for Food, Roads and Rural Infrastructures, the National Directorate of Employment, the Better Life Programme, the Peoples' Bank, the Community Banks, the Family Support Programme and the Family Economic Advancement Programme. The democratic era witnessed the introduction of the Poverty Alleviation Programme (PAP) designed to provide employment to 200,000 people all over the country(Ijaiya et al., 2011). It was also aimed at inculcating and improving better attitudes towards a maintenance culture in highways, urban and rural roads and public buildings. By 2001 PAP was phased out and fused into the newly created National Poverty Eradication Programme (NAPEP) which was an integral part of the National Economic Empowerment and Development Strategy (NEEDS).

Globally, disasters have continued to cause severe catastrophic consequences in the loss of human lives as well as economic losses. For example, the magnitude 9.2 earthquake that occurred in the Indian Ocean on December 26, 2004, caused a large tsunami that flooded more than ten coastal countries and culminated in about 300,000 deaths with severe economic and environmental impacts(James et al., 2013). Similarly, between August 23, and August 30, 2005, Hurricane Katrina in the Gulf of Mexico led to 1,400 deaths with severe economic losses(James et al., 2013). Nevertheless, Nigeria is not located in high-prone natural disaster (e.g. earthquake, hurricane) zones, but the country has experienced cases of floods, coastal erosion, sand storms, landslides, oil-spillage, and desertification disasters. These disasters have resulted in the loss of lives as well as properties. For example, the first flood hit Ibadan, the headquarters of old western region, Nigeria (now the capital of Oyo State) was in 1948. Subsequently, serious flood disasters have occurred in Ibadan in 1963, 1978, April 30, 1980, 1985, 1987, and 1990 destroying many valuable things (Adedeji et al, 2012). About 100 people died in Ibadan due to flood in 2011 while 5,000 people were displaced with severe economic impacts (James et al., 2013).

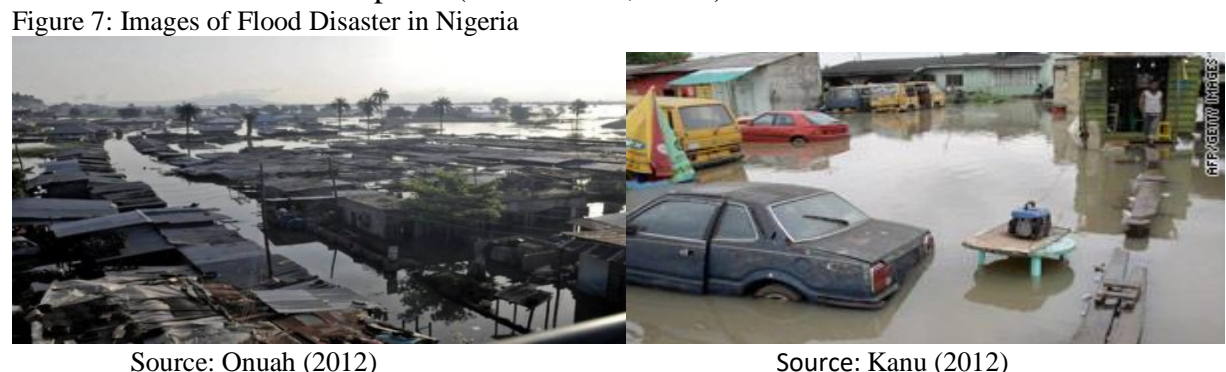

Lagos metropolis recorded the first flood in early 1970s and till date, floods (both river and coastal floods) have become perennial event in the state. Most recently about 700 inhabitants of settlements along the River Ogun in Lagos state were evacuated to refugee/relief camp after a devastating flood that plagued the area around October 12, 2010 by the Lagos State Emergence Management Agency(Adedeji et al, 2012). The devastating flood disaster that occurred on the 26th of August 2011 caused a lot of woes to people around the Eleyele wetlands in Ibadan,southwest, Nigeria destroying lives and properties around Apete, Idi-Ishin, Apata, Odo-OnaElewe, Oke-Ayo, Ologuneru and University of Ibadan where the university library and Zoological Garden were badly affected.

About 300,000 animals representing 13 per cent of the livestock population of north-eastern Nigeriawere estimated to have died (Disaster management, n.d.)during the drought of 1972-1973, agricultural yields dropped to between 12 per cent and 40 per cent of the annual averages (Disaster management, n.d.). In the drought of year 1987, crop yields ranged between 56 per cent and 75 per cent of the 1986 totals (Disaster management, n.d.). The consequences of environmental breakdown as a result of a prolonged drought led to massive economic losses, destruction of ecological resources food shortages and starvation for millions of people (Disaster management, n.d.).

In the early 80 's, Nigerians were petrified when a mild tremor rocked Ibadan, Ijebu-Ode and Shagamu, three cities in the country's South West. No casualties were recorded in the incident, neither were any buildings felled. But till date, the memory lingers (Igomu, 2010). In 2009, Researchers at the National Space Research and Development Agency (NARSDA) officially warned about the possibility of an earthquake disaster in Nigeria's South Western 
region. They made reference to a tremor that rocked the region in September 11, 2009, stressing that Nigeria is no longer immune from earthquakes (Igomu, 2010). See Tables 4 and 5 below for an overview of natural disasters in Nigeria for the period 1980 to 2010 and the average per year.

Table 4: Overview: Natural Disasters in Nigeria from 1980-2010

$$
\text { No of Events }
$$$$
94
$$

\begin{tabular}{ll}
\hline No of people killed & 21,002 \\
\hline Average killed per year & 677 \\
\hline No of people affected & $6,306,441$ \\
\hline Average affected per year & 203,434 \\
\hline Economic Damage (US\$ X 1,000) & 188,025 \\
\hline $\begin{array}{l}\text { Economic Damage per year (US\$ } \\
\text { X 1,000) }\end{array}$ & 6,065 \\
\hline
\end{tabular}

Table 5: Average Disaster per Year

\begin{tabular}{ll}
\hline Drought & $\mathbf{0 . 0 3}$ \\
\hline Earthquake & $\ldots$ \\
\hline Epidemic & 1.58 \\
\hline Extreme temp & 0.06 \\
\hline Flood & 0.06 \\
\hline Mass mov. dry & $\ldots$ \\
\hline Mass mov. wet & 0.10 \\
\hline Volcano & $\ldots$ \\
\hline Storm & 0.06 \\
\hline Wildfire & $\ldots$ \\
\hline
\end{tabular}

Source: Prevention Web (2013)

The vulnerability of a population is a determinant of a disaster, as this essentially decides whether ra hazard remains a hazard, or whether through contact with a vulnerable population this hazard turns into a disaster (Prowse 2003). This implies on the one hand, that the poverty situation in which a person lives shapes his/her vulnerability and the degree of impact the disaster has on him/her. On the other hand, the impact of the disaster affects people's future vulnerability and thus influences their poverty situation. Nigeria is vulnerable to many hazards, including, but not limited to, fires, flooding, transportation and industrial accidents, and political conflicts (Ibem, 2011). Nigeria is vulnerable to these and other hazards and disaster impacts because of high population densities in urban areas (50\% of Nigerians live in urban areas) (Nwaka, 2005) (scarcity of land has led to inordinate construction of structures in hazardous areas), an inability to integrate risk reduction measures into national development plans and programs (Abang, 2005), and poverty (NDMF, 2010).

4. International Disaster Management Initiatives

Although natural disasters cannot be avoided, studies have shown that adequate disaster management plan can reduce its impacts on lives and properties. Moreover, disasters often do not respect national or international boundaries. As a result, governments and international organizations are cooperating to promote global and regional initiatives to address the full/partial disaster management cycle consisting of mitigation, preparedness, response and recovery (James et al., 2012).

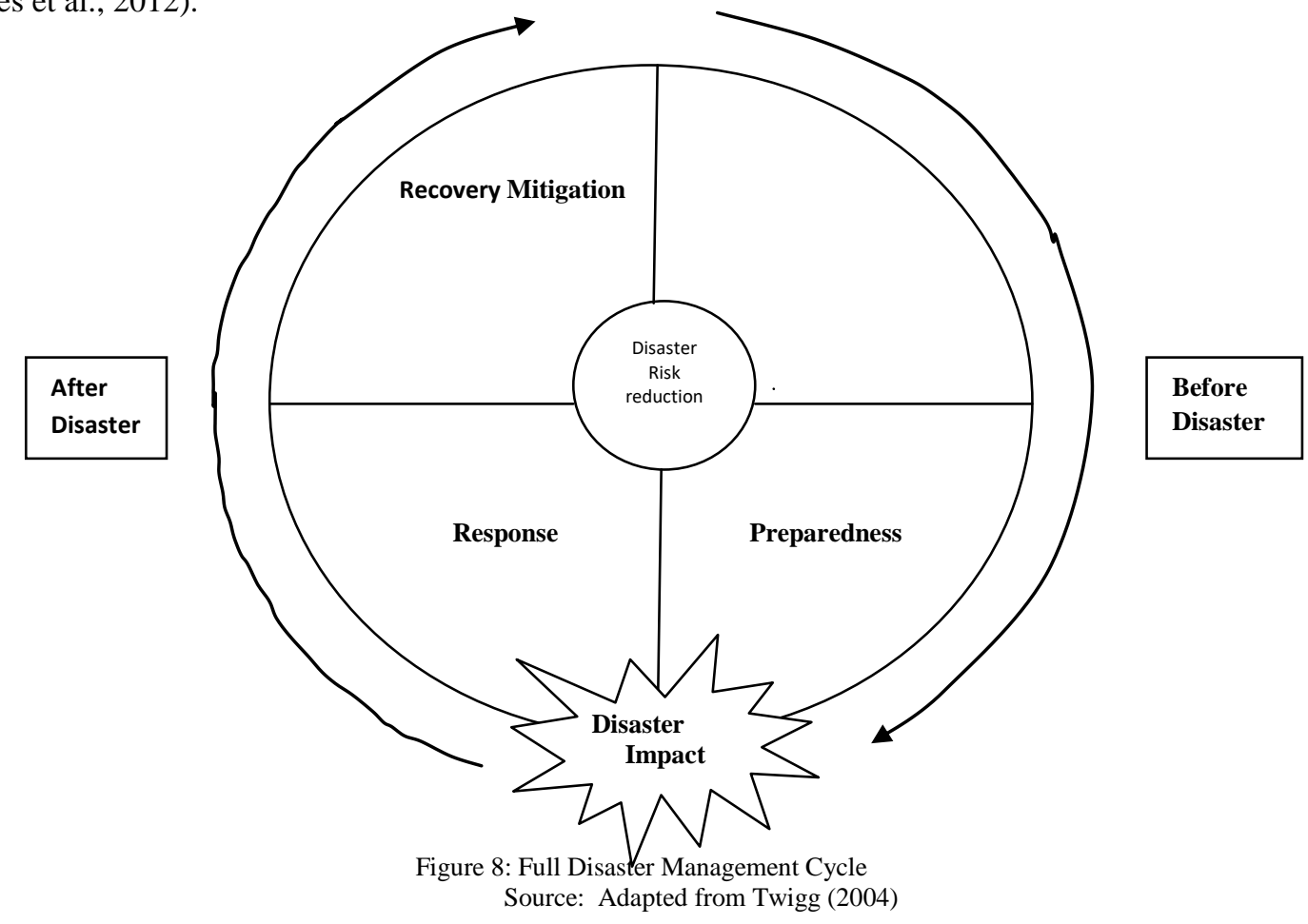


Some of these initiatives are: The International Charter "Space and Major Disasters" (ICSMD), Disaster Monitoring Constellation (DMC), The United Nations Platform for Space Based Information for Disaster Management and Emergency Response (UN-SPIDER), and The United Nations International Strategy for Disaster Reduction (UNISDR) (James et al., 2013).

4.1 Introduction of Space Technology in Disaster Mitigation and Management in Nigeria

Recognizing the significant role of space technology in the attainment of rapid sustainable socio-economic development, the Federal Government of Nigeria took a bold step by putting in place a space policy and space science and technology programme. Subsequently, in 1999, an institutional framework, the National Space Research and Development Agency (NASRDA), was established. The first Nigerian earth observation satellite - NigeriaSat-1 was successfully launched into Low Earth Orbit (LEO) from Plesetsk, Moscow, on 27 September 2003 on a Kosmos Rocket along with two other Disaster Monitoring Constellation (DMC) micro-satellites - UK DMC, and BILSAT (Turkey satellite).The choice of a micro-satellite using current technology was influenced by its low cost, affordability, and the advantage of performance comparable with the expensive large satellites and the possibility of supporting capacity building(Boroffice, 2008).

NigeriaSat-1 is a micro-satellite deployed in to a polar sun-synchronous orbit at an altitude of $686 \mathrm{~km}$. It is a $100 \mathrm{~kg}$ spacecraft with Push-broom scanning technology, and designed for a 5-year minimum lifespan. It has a swath width of $600 \mathrm{~km}$ and the imaging payload is 3-band multi-spectral imager in the green, red and near-infrared bands 0.52 0.62 (Green), 0.63-0.69 (Red), 0.76-0.9 (NIR) and has a Ground Sampling Distance (GSD)/spatial resolution of $32 \mathrm{~m}$ (Boroffice, 2008). The spacecraft has on-board data storage capacity of $2 \times 0.5$ Gbyte SSDR to support imaging activities, with a store and forward communications system. It has a space-bourne GPS for orbit determination, two on-board computers for data processing, and a butane propulsion system for orbit maintenance/station keeping(Boroffice, 2008).NigeriaSat-1 is one of the five satellites of the Disaster Monitoring Constellation (DMC) built to address the need for daily revisit and global coverage to monitor natural disasters and other dynamic phenomena.

Taking into account the reality of direct access to affordable, real-time and reliable space-derived data, the NigeriaSat-1 data has been used in many projects some of which are: Flood hazards/risk mapping in the Shiroro Dam area; Mapping of settlements and major roads and water bodies; gully erosion mapping in the south eastern part of Nigeria; monitoring deforestation and implications for bio-diversity in Nigeria; predictive model for desertification early warning; patio-temporal assessment of climate and human- induced impact on ecosystem degradation and water resources management; and land use/land cover.

To ensure continuity, NigeriaSat-2 was introduced. It carries the 32-m multi-spectral payload in NigeriaSat-1.It provides valuable geographically referenced high-resolution satellite imaging for applications in mapping, water resources management, agricultural land use, population estimation, health hazard monitoring and disaster mitigation and management.

In summary, satellites monitoring Earth's resources and natural disasters have different repeat pass frequency and spatial resolution (unless it belongs to the same series of satellites for the purpose of continuation of data flow with same specifications). Similarly, different satellites have different types of sensors on-board, such as, panchromatic, multispectral, infrared and thermal. All these sensors have applications in disaster mitigation, though depending on the electromagnetic characteristics of the objects on Earth and the nature of disaster itself (Nirupama and Simonovic, 2002).

Prior to the use of space technology in Nigeria, it was a major challenge to identify communities devastated by disasters (particularly natural disasters in the rural areas) using terrestrial approaches. This is particularly true since access to such remote areas is often made impossible by the disaster. However, access to earth observation satellite imagery provides a solution by enabling synoptic view of areas affected by disasters as well as the optimum access to such areas. The results from the use of space technology have enhanced the ability of NEMA to respond to disasters swiftly and efficiently in Nigeria between 2010 and 2012 for floods in Sokoto (Charter Call 324 and 326), Ibadan (Charter Call 370), and Adamawa (Charter Call 407), Kogi (Charter Call 415), Bayelsa (Charter Call 416), respectively (James et al., 2013). See Appendix for satellite images ofRivers stateand Bayelsa State flood disaster.

\section{Obstacles in Disaster Risk Reduction in Nigeria}

Nigeria like any other African country has some major gaps in the practice of disaster risk reduction as pointed out in a baseline study undertaking inthe first phase of the development of the Africa Regional Strategy on Disaster Risk Reduction. Disaster risk reduction is yet to be effectively institutionalized in Nigeria. Although the National Emergency Management Agency (NEMA) has been established to oversee a more holistic approach to the management of disasters in all phases and all associated consequences, however, sub-regional disaster management programmes in the country are yet to be developed. Technical institutions like the 
Nigerian Meteorological Agency are few and their services are limited due to resource, capacity and other constraints.

Government has a key responsibility to create the facilitating environment in which people can be empowered to prevent or reduce natural disaster risks. However, because of the failure or absence of development that can arise partly from an unfavorable environment, people are highly vulnerable to disaster risks in Nigeria. For example, key sectoral policies, such as on food and agriculture, rural and urban development and enterprise development, do not sufficiently consider how they impact people's vulnerability to hazards. Furthermore, there is no tax or financial incentives to promote greater use of engineered and disaster-resistant construction. Also, for so long most disaster management structures focus on one or two key natural hazards, mainly flood and drought. Policy frameworks rarely cover small localized disasters. The practice of risk identification is limited in Nigeria. Early warning systems are only now being developed.

The ability of people to take informed actions to secure their safety during disasters also depends on availability of timely and targeted information on disaster risk reduction. A major gap in disaster risk reduction in Nigeria is weak knowledge management. There is inadequate attention to information management and communications, and training and research. Consequently, there are gaps in knowledge about disaster risks.

Nigeria's space exploration still requires more infrastructure. The cost of space infrastructure - launchers, in-space systems and supporting ground operations, human activity in space, and the knowledge and technology base that supports the infrastructure is so exorbitant.

In practice, national disaster risk reduction structures in Nigeria generally suffer from inadequate financial support. Inadequate financing for disaster risk reduction is the result of many factors including the low priority accorded to disaster reduction in national budgeting; lack of dedicated disaster funding mechanisms, etc.

5.1 Way Forward

Prospective assessment of the risk of disasters to development and the effect of development interventions on disasters, effective early warning of impending risks, and systematic assessment of disaster losses are particularly important in helping communities and the country to determine and understand the actions which they may take in order to reduce the impact of potential and existing risks.

To help enhance access to information and to expand information dissemination, there is the need to strengthen disaster risk reduction information services and public communications mechanisms, including space technology and geographical information systems. It is necessary to encourage and facilitate public-private partnerships that increase the availability of and accessibility to these means of disaster risk information and communications.

For disaster risk reduction communications systems to empower communities threatened by impending disasters, risk reduction information must be provided in good time, precise, prompt, reliable and actionable. Effective disaster risk reduction communications requires that the target population not only receives advance information on hazards and vulnerability changes but also that they understand the content of the message, accept it, believe it and know how to use it to guide their response actions. Public education and awareness-strengthening processes about potential risks and the role of risk information in disaster risk reduction needs to be continuous to promote this process. Public awareness needs to be undertaken through all means of communications interaction between disaster risk reduction authorities and the public and at all levels.

Facilitating participatory design and implementation of disaster risk reduction interventions can increase people's participation in them. Institutionalizing risk reduction at the local level involves modern management approaches that emphasize decentralized and coordinated partnerships between disaster management agencies and the people, based on the principle of self-consent. It is therefore important to encourage governments to accelerate the decentralization of disaster risk reduction mechanisms, particularly local-level risk management interventions.

Given the explicit cause-and-effect links between disasters and development interventions, development policy should aim at reducing basic societal risks while attaining sustainable development objectives. Balancing these two goals requires incorporating disaster risk reduction in development policies, strategies and programmes at local and national.

6. Conclusion

Orbiting in space, satellites can cover vast and remote areas of the Earth over many years spanning national boundaries and detecting global patterns of environmental change not easily observed from the ground. Data from satellites, collected digitally, can be processed with specialized computer software yielding accurate, timely and useful information products which inform decision- and policy-making. At global and regional scales, thanks to space technology, knowledge of the various components of the Earth system is improving.

Investment towards making use of the space technology is worth because improvement in instrumentation and real time prediction will bring about reduction in disaster damages; better prediction; accurate and timely damage 
estimation; and improved decision making in planning stages. Nigeria, therefore, needs to embrace and effectively incorporate the use of satellite technology based solutions in its effort at disaster management and poverty reduction.

References

Abang, B. E. (2005)."Threats to the built environment in Nigeria by possible disaster event at Lake Nyos and the CumbreVieja volcano." Pp. 17-28 in Alabi, A.S. and Sam-Epelle, A.O. (eds.) Proceedings of the 1st National Built Environment Summit Organized by the Nigerian Institute of Architects and the Nigeria Institute of International Affairs, Victoria Island,Lagos, 8-10 February 2005, Nigerian Institute of Architects: Lagos.

Adedeji,O. H.,Odufuwa, B.O., and Adebayo, O. H. (2012).Building capabilities for flood disaster and hazard preparedness and risk reduction in Nigeria: Need for spatial planning and land management.Journal of Sustainable Development in Africa, 14(1), 45-58.

African Development Bank (2010). Gender, Poverty and Environmental Indicators on African Countries 2010 Abidjan: ADB

Benson, C., and Clay,E.J. (1998).The Impact of Drought on Sub-Saharan African Economies: A Preliminary Examination. World Bank Technical Paper 401. Washington, D.C.

Benson, C., and Clay, E. J. (2004).Understanding the economic and financial impacts of natural disasters.Disaster Risk Management Series 4.World Bank.Washington, D.C.http://wwwwds.worldbank.org/servlet/WDSContentServer/WDSP/IB/2004/04/20/000012009_20040420

Boeninger, E. (1991). Governance and Development: Issues and Constraints. Proceeding of the World Bank Annual Conference in Development Economics. 1991. Washington. D.C: The World Bank.

Boroffice, R.A. (2008).The Nigerian space programme: An update. National Space Research \& Development Agency (NASRDA), Abuja, Nigeria.http://www.saao.ac.za/ wgssa/archive/as12/boroffice.pdf

Disaster Management (n.d).Disaster management and data needs in Nigeria. Retrieved fromhttp://webcache.googleusercontent.com/search?q=cache:iQKqvpEkrzQJ:www.oosa.unvienna.org/pdf/ sap/2002/ethiopia/presentations/3speaker03_1.pdf+overview+of+natural+disaster+in+nigeria\&hl=en\&gl=u $\mathrm{k}$

Economic Watch (2010).Nigeria Economy.http://www.economywatch.com/world_economy/nigeria

Eschborn (2005).Linking poverty reductionand disaster risk management.http://www.unisdr.org/we/inform/publications/3293

EU (2013).EU experts help Nigeria prepare for floods.http://ec.europa.eu/echo/news/2013/20130813_en.htm.

Fabiyi, O. (n.d.).Real time space remote sensing data and GIS for oil spill disaster management in Nigerian Niger Delta: A call for paradigm change.http://www.oosa.unvienna.org/pdf/sap/2002/ethiopia/presentations/11speaker11.pdf

Federal Office of Statistics (FOS) (various issues). Annual Abstract of Statistics. Lagos: FOS.

Francis, P., Akinwumi, J.A., Ngwu, P., Nkom, S.A., Odili, J., Olamajeye, J.A., Okunmadewa, F., and Shehu, D.J. (1996).State, Community and Local Development in Nigeria.World Bank Technical Paper No. 1440.

GTZ (2002).Disaster risk management.Working Concept.Eschborn: German Technical Co-operation (GTZ).

Ibem, E. O. (2011). "Challenges of disastervulnerability reduction in Lagos megacity rea, Nigeria."Disaster Prevention and Management. 20 (1), 27-40.

IFRC (2012). What is a disaster? URL: http://www.ifrc.org/en/what-we-do/disaster-management/aboutdisasters/what-is-a-disaster/. Accessed: 15th October 2012

Igomu, T. (2010). How Nigeria can combat natural disasters.http://www.nigerianbestforum.com/blog/how-nigeriacan-combat-natural-disasters/

Ijaiya, G.T., Ijaiya, M. A. A., Bello, R. A., and Ajayi, M. A. (2011).Economic growth and poverty reduction in Nigeria.International Journal of Business and Social Science, 2(15), 147-154.

James, G., Shaba, H., Zubair,O., Teslim, A., Yusuf,G. Nuhu, A. (2013).Space-based disaster management in Nigeria: The role of the international charter "space and major disasters". FIG Working Week 2013, Environment for Sustainability ,Abuja, Nigeria, 6 - 10 May.http://www.fig.net/pub/fig2013/papers/ts01c/TS01C_james_halilu_et_al_6539.pdf

Kanu, A. (2012).End Of The Road? A Special Report On The Nigeria Flood Disaster.http://www.nigeriavillagesquare.com/ahaoma-kanu/end-of-the-road-a-special-report-on-thenigeria-flood-disaster.html

National Emergency Management Agency (NEMA) (2010). "National disaster management framework (NDMF)."Accessed January 14, 2012 ,

Ngex.com(n.d.).An Overview of Nigeria.http://www.ngex.com/nigeria/overview.htm 
Nirupama and Simonovic, S. P. (2002).Role of remote sensing in disaster management.http://ir.lib.uwo.ca/cgi/viewcontent.cgi\%3Farticle\%3D1002\%26context\%3Dwrrr

Nwaka, G. I. (2005). "The urban informal sector in Nigeria: Towards economic development, environmental health and social harmony."Global Urban Development Magazine. 1 (1), 1-11.

Obadan, M. I. (n.d.). Poverty reduction in Nigeria: The Way forward.http://www.cenbank.org/OUT/PUBLICATIONS/EFR/RD/2002/EFRVOL39-4-3.PDF

OECD (2001).The DAC Guidelines Poverty Reduction.Paris: Organisation for Economic Co-operationand Development (OECD).

ODI (2005). Aftershocks: Natural disaster risk and economic development policy. ODI Briefing Paper.http://www.odi.org.uk/resources/docs/2596.pd

Ogwumike, F.O (2001). Appraisal of poverty and poverty reduction strategies in Nigeria.CBN Economic and Financial Review. 39(4),45-71.

Okuyama,Y. (n.d.).Economic impacts of natural disasters: Development issues and applications. Research supported by the Global Facility for Disaster Reduction and Recovery (GFDRR), the World Bank.http://nexusidrim.net/idrim09/Kyoto/Okuyama.pdf.

Onuah, F. (2012).Nigeria flood disaster 'worst since 1948' - More than 600,000 people displaced, 589 square miles of farmland destroyed - Crocodiles and hippos washed into homes. http://www.desdemonadespair.net/2012/10/nigeria-flood-disaster-worst-since-1948.html.

Oyeranti,O., and Olayiwola, K. (2005).Policies and programmes for poverty reduction in rural Nigeria.An Interim Research Report Submitted to the African Economic Research Consortium (AERC), Nairobi for the Second Phase Collaborative Poverty Research Project.http://www.sarpn.org/documents/d0002274/Poverty_reduction_Nigeria_Oct2005.pdf.

Özerdem, A. (2003). Disaster as manifestation of unresolved development changes: The Maramara earthquake, Turkey. In: Pelling, M. (Ed.): Natural disasters and development in a globalizing world. London:Routledge, p. 199-213.

PreventionWeb

(2013)

Nigeria

Disaster

Statistics http://www.preventionweb.net/english/countries/statistics/?cid=126

Picciotto, R (1992). Participatory Development: Myths and Dilemmas. World Bank Policy Research Working Paper No.930

Prowse, M. (2003).Towards a clear understanding of 'vulnerability' in relation to chronic poverty.Manchester: Graduate School of Social Science and Law, University of Manchester.

Quarantelli, E.L. (Ed)(1998). What is a disaster? Perspectives on the question. London: Routledge.

Royal Society(1992).Risk: Analysis, Perception and Management. London.

Tiena(2010).Poverty and Nigeria’s booming population.http://questionmarkmag.com/2010/09/poverty-and-nigeriasbooming-population

Twig J. (2004). Disaster risk reduction: Mitigation and preparedness in development and emergency programming. Good Practice Review. Number 9, March.

UNDP (1994).Disasters and Development.Disaster Management Training Program.Modulepreparedby Stephenson R. S.. New York: United Nation Development Program (UNDP). (Available at:http://undmtp.org/english/disaster_development/disaster_development.pdf).

United Nations (UN) (2002).Human Rights and Extreme Poverty. New York: UN.

United Nations (2004).Guidelines for a Human Rights Approach to Poverty Reduction Strategies. High Commissioner for Human Rights. New York: United Nations.

Woolcock, M., and Narayan, D. (2000 ). Social capital: Implications for development theory, research and policy. World Bank Research Observer, 15(2),225- 250.

Appendix

Table 2: Estimated Total Population and Rate of Poverty in Nigeria (1980-2002)

\begin{tabular}{llll}
\hline Year & $\begin{array}{l}\text { Estimated Total } \\
\text { Population } \\
\text { million) }\end{array}$ & $\begin{array}{l}\text { Absolute No. } \\
\text { of Poor People } \\
\text { million) }\end{array}$ & (in $\begin{array}{l}\text { Percentage } \\
\mathbf{\%}) \\
\text { that are Poor }\end{array}$ \\
\hline 1980 & 64.6 & 18.1 & 28.1 \\
\hline 1981 & 66.7 & 21.3 & 32.0 \\
\hline 1982 & 68.4 & 24.2 & 35.5 \\
\hline 1983 & 70.6 & 27.5 & 39.0 \\
\hline 1984 & 73.0 & 31.4 & 43.0 \\
\hline 1985 & 75.4 & 34.9 & 46.3 \\
\hline
\end{tabular}




\begin{tabular}{lccc}
\hline 1986 & 77.9 & 35.8 & 46.0 \\
\hline 1987 & 80.4 & 36.5 & 45.4 \\
\hline 1988 & 83.1 & 37.4 & 45.0 \\
\hline 1989 & 84.9 & 37.7 & 44.5 \\
\hline 1990 & 86.6 & 38.0 & 44.0 \\
\hline 1991 & 88.5 & 38.5 & 43.5 \\
\hline 1992 & 91.3 & 39.0 & 42.7 \\
\hline 1993 & 93.5 & 45.8 & 49.0 \\
\hline 1994 & 96.2 & 52.6 & 54.7 \\
\hline 1995 & 98.9 & 59.3 & 60.0 \\
\hline 1996 & 102.3 & 67.1 & 65.6 \\
\hline 1997 & 104.0 & 67.6 & 65.5 \\
\hline 1998 & 106.3 & 68.0 & 69.5 \\
\hline 1999 & 109.3 & 72.3 & 72.0 \\
\hline 2000 & 111.3 & 77.0 & 74.0 \\
\hline 2001 & 114.0 & 81.2 & 83.1 \\
\hline 2002 & 116.4 & 86.0 & 88.0 \\
\hline \multicolumn{5}{c}{ Source: (Ijaiya et al., 2011) } \\
\hline
\end{tabular}

Table 3: Socio-economic Indicators in Nigeria- 1970-2001

\begin{tabular}{|c|c|c|c|c|c|c|c|c|}
\hline Year & $\begin{array}{l}\text { Access } \\
\text { to } \\
\text { Health } \\
\text { Care } \\
(\%)\end{array}$ & $\begin{array}{l}\text { Access } \\
\text { to } \\
\text { Water } \\
\text { Care } \\
(\%)\end{array}$ & $\begin{array}{l}\text { Adult } \\
\text { Illiterac } \\
\text { y }(\%)\end{array}$ & $\begin{array}{l}\text { Access } \\
\text { to } \\
\text { Sanitat } \\
\text { ion } \\
(\%)\end{array}$ & $\begin{array}{l}\text { Life } \\
\text { Expectanc } \\
\text { y at Birth } \\
\text { ( Years) }\end{array}$ & $\begin{array}{l}\text { Per } \\
\text { Capita } \\
\text { Income } \\
(\$)\end{array}$ & $\begin{array}{l}\text { Infant } \\
\text { Mortalit } \\
\text { y (Per } \\
\text { 1000) }\end{array}$ & $\begin{array}{l}\text { Daily } \\
\text { Calorie } \\
\text { Intake } \\
\text { ( Per } \\
\text { Capital) }\end{array}$ \\
\hline 1970- 74 & - & - & 89.7 & - & 43.2 & 350.0 & - & - \\
\hline $1975-79$ & - & - & 84.9 & - & 45.3 & 660.0 & 122.0 & 1962 \\
\hline $1980-84$ & 40.0 & - & 67.1 & - & 47.4 & 410.0 & 112.0 & 1903 \\
\hline $1985-89$ & 40.0 & 15.9 & 59.2 & 62.1 & 49.2 & 270.0 & 102.0 & 2291 \\
\hline 1990-95 & 67.0 & 40.0 & 51.4 & 63.3 & 50.4 & 220.0 & 93.4 & 2656 \\
\hline 1995 & - & 49.9 & 43.6 & 57.3 & 51.1 & 210.0 & 91.6 & 2802 \\
\hline 1996 & - & - & 42.1 & - & 51.2 & 250.0 & 89.8 & 2772 \\
\hline 1997 & - & - & 40.6 & - & 51.3 & 270.0 & 88.0 & 2779 \\
\hline 1998 & - & - & 39.1 & - & 51.5 & 260.0 & 86.2 & 2828 \\
\hline 1999 & - & - & 37.6 & 63.0 & 51.6 & 250.0 & 84.4 & 2833 \\
\hline 2000 & - & - & 36.1 & 63.0 & 51.8 & 260.0 & 82.6 & - \\
\hline 2001 & - & - & 34.7 & - & 51.9 & 290.0 & 75.1 & - \\
\hline 2005 & - & - & 29.2 & - & 46.8 & 620.0 & 111.9 & 2654.7 \\
\hline 2006 & - & 47.0 & 28.1 & 30.0 & 46.8 & 830.0 & 110.7 & - \\
\hline 2007 & - & - & 26.9 & - & 49.9 & 970.0 & 109.5 & - \\
\hline 2008 & - & - & - & - & - & 1160.0 & - & - \\
\hline
\end{tabular}

Source: (Ijaiya et al., 2011).

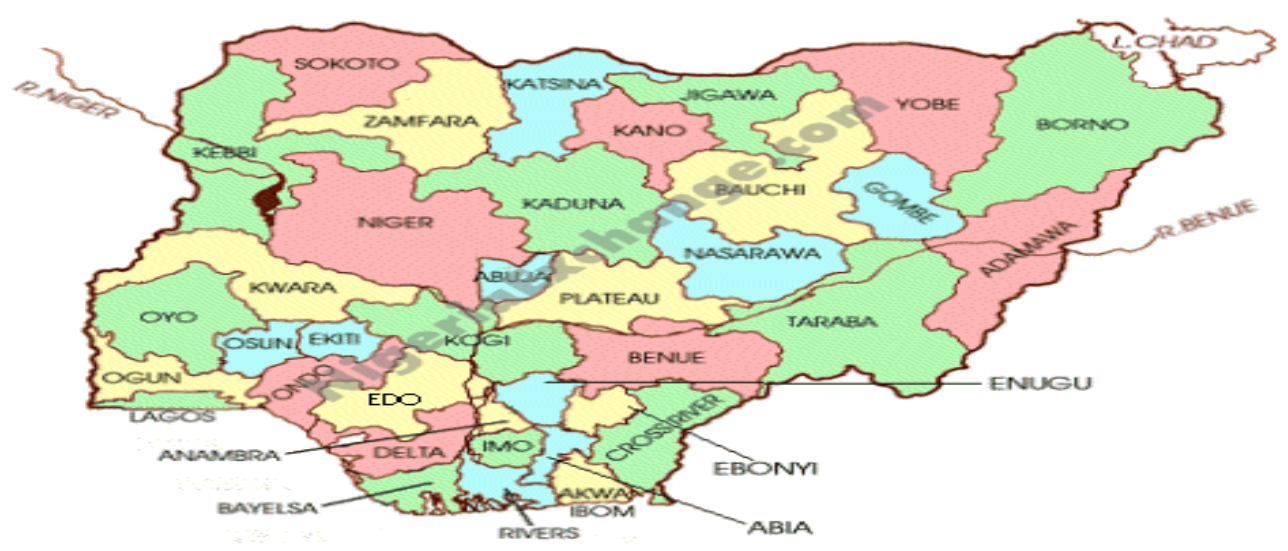

Figure 6: Map of Nigeria

Source:Ngex.com(n.d. 
Satellite Images of Rivers State and Bayelsa State Flood Disaster

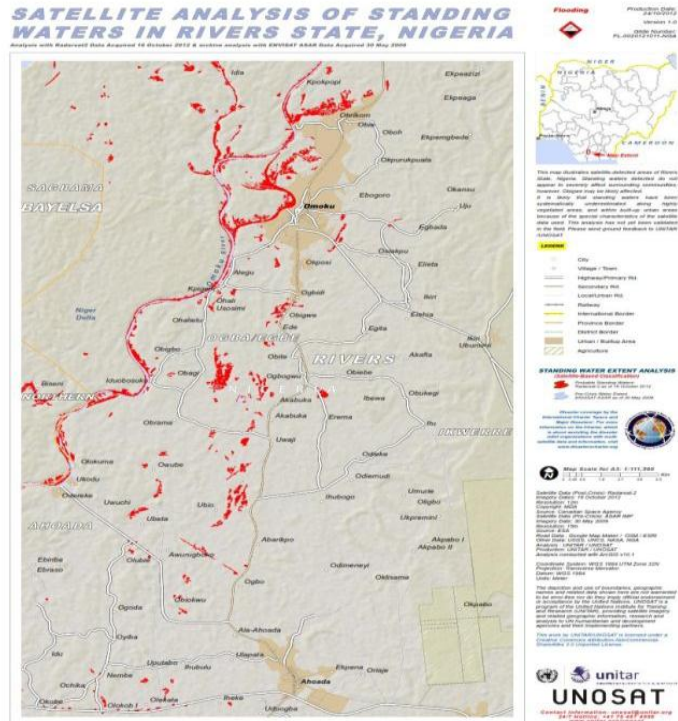

Figure 9: Flooded Areas in Parts of Rivers State.

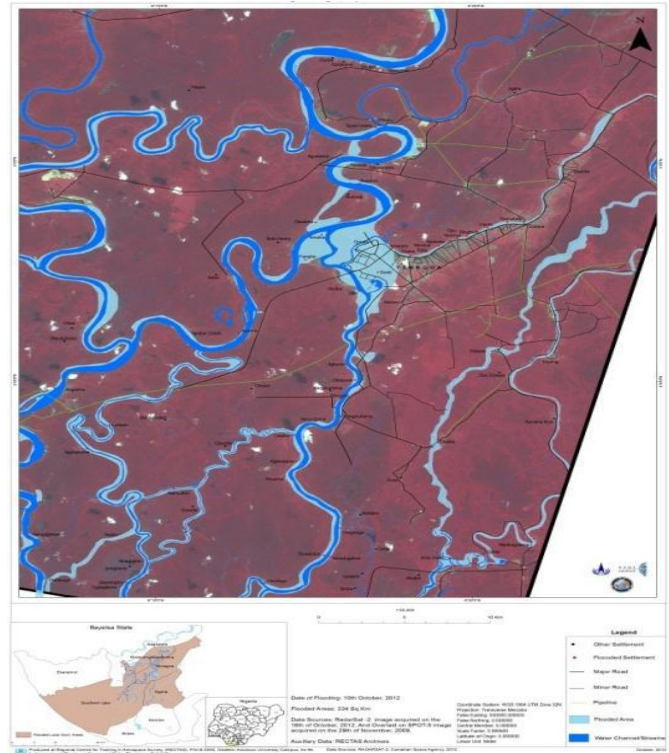

Figure 10: Flooded Areas in Yenagoa and Environs

The map products generated from the image analysis of 2012 flooding in Rivers and Bayelsa states are presented in Figures 9 and10.The incidence of floods in Rivers state was notso severe, affecting only Idia, Omoku, Obikwe and Biseni communities, among others. On the other hand, it was very severe in Bayelsa state. The total area impacted by the floods was 334 sq., affecting virtually all communities south of Yenagoa (Figure 8).

Source: James et al. (2013)

\section{Copyrights}

Copyright for this article is retained by the author(s), with first publication rights granted to the journal.

This is an open-access article distributed under the terms and conditions of the Creative Commons Attribution license (http://creativecommons.org/licenses/by/4.0/) 